\title{
Development of Acid-Base Devices Integrating ARCS Motivation Strategy in Problem-Solving Learning Model Scientific Attitude and Critical Thinking Skills of Students
}

\author{
Melania Priska1 ${ }^{*}$, Natalia Peni², Yosephina Payu Wao ${ }^{1}$ \\ ${ }^{1}$ Biology Education, University of Flores, Ende, Indonesia \\ ${ }^{2}$ Mathematics Education, University of Flores, Ende, Indonesia
}

DOI: $10.29303 /$ jppipa.v7iSpecialIssue.1126

\section{Article Info}

Received: November $13^{\text {th }}, 2021$

Revised: December 12th, 2021

Accepted: December 15th, 2021

\begin{abstract}
The purpose of this research is to develop an acid-base device that integrates ARCS motivation strategies in problem-solving learning models of scientific attitudes and critical thinking skills of students. The development of this device uses a 4-D model, but in this study, due to the limited time, the development of the device only reached the development stage and was tested on Biology Education Study Program students in semester 2 with a one-group pretest-posttest design. Data collection techniques used are validation, tests, and questionnaires. Data were analyzed using SPSS and the Likert scale. The results showed the validity of the Semester Lesson Plan obtained a $r_{\text {count }}$ of 0.690 , valid category. Student Worksheet obtained $r_{\text {count }}$ value of 0.748 valid categories. Learning Outcomes Test obtained, $r_{\text {count }}$ of 0.701 , with a valid category. The percentage of Lesson Plan implementation is on a scale of 4 with a good category. The results of the N-Gain Score test in the productive class is $78.58 \%$ effective category while the N-Gain Score in the trial class is $70.14 \%$ and is included in the quite effective category. The data shows that learning using ARCS motivation strategies in problem-solving learning models can improve student learning outcomes.
\end{abstract}

Keywords: Problem Solving Learning Model; ARCS Motivation Strategy; Critical Thingking Skills; Scientific Attitude.

Citation: $\quad$ Priska, M., Peni, N., \& Wao, Y.P. (2021). Development of Acid-Base Devices Integrating ARCS Motivation Strategy in Problem-Solving Learning Model Scientific Attitude and Critical Thinking Skills of Students. Jurnal Penelitian Pendidikan IPA, 7(SpecialIssue). https:/ / doi.org/10.29303/jppipa.v7iSpecialIssue.1126

\section{Introduction}

The education system for higher education has oriented to the achievement of learning quality. Graduate competency standards in learning outcomes include attitudes, knowledge, and skills. Graduate competencies are more focused on life skills. Higher education is increasingly important to ensure that students have the skills to learn and innovate, the skills to use technology and information media, and can work and survive using the skills they have. In reality, student creativity is still not considered and trained in learning. That is due to the pattern of education in Indonesia which emphasizes the rote method. Students are usually not encouraged to ask questions and think according to their imagination. If students continue to be restrained by lecturers in the learning process, it will harm the development of student creativity (Khairani \& Safitri, 2017).

A learning process has a goal to improve and achieve achievement. The motivation between lecturers and students is one aspect that is very important and very influential on the achievement of the desired learning objectives. The low learning motivation of students is influenced by several factors. When the lecturer enters the class and wants to start learning, some students are still not ready and many are still busy with their work. Students are still less active in the learning process and tend to be lazy

\footnotetext{
*Email: pika87cutes@gmail.com
} 
to pay attention to the lecturer's explanation. Even during the learning process, students are often found engrossed in playing cellphones, chatting, listening to music, and having an impact on the commotion in the classroom. In addition, the existing learning tools in universities are still not facilitated in learning and there are still lecturers who teach using makeshift learning tools. Lecturers' lack of knowledge of learning tools causes low student learning motivation (Yardi, 2015; Wahidah, et al., 2019).

The low motivation to learn is also caused by the lack of interest of students in one course. This lack of interest is caused by students having a low scientific attitude, where a scientific attitude can encourage students to be actively involved in the learning process, because of their inner curiosity. The scientific attitude that must be possessed by students consists of being curious, patient, open, critical, objective, honest, humble, and sensitive to the surrounding environment (Purwanti \& Manurung, 2015). Problems in the environment around students are real experiences that are encountered and experienced directly to train students' critical thinking skills. The environment can be used as a learning resource that can stimulate students' thinking attitudes towards the problems to be investigated and analyzed to find solutions to problems through experiments (Priska, et al., 2020).

The subject that is often considered difficult and boring is laboratory engineering. Laboratory engineering is a science that plays an important role in life processes and has links with other sciences such as chemistry, biology, physics, and other sciences. The low quality of the achievement of laboratory engineering learning outcomes is not only caused by lazy students, it requires a scientific attitude and critical thinking skills. In addition to the scientific attitude and critical thinking required, interesting learning methods are also needed (Sukaesih, 2011). Based on the description above, the researchers tried to develop a direct teaching model with ARCS motivation strategies and problem-solving methods to increase students' motivation in studying acid and base which in turn had an impact on improving their learning outcomes.

One of the lessons that can increase student motivation is Attention, Relevance, Confidence, Satisfaction (ARCS). ARCS learning begins with motivating to focus students' attention. Students are given a positive attitude that the course is beneficial for their lives. If you are motivated and have a positive attitude, then the material can be absorbed well. The ARCS learning model prioritizes attention, adapts learning materials to the learning experience, creates self-confidence, and creates a sense of satisfaction. This model is interesting because it was developed based on the theories and real experience of the instructor so that it can generate enthusiasm for learning optimally by motivating oneself so that optimal learning outcomes are obtained. Previous research also supports that the ARCS strategy with direct teaching arrangements can increase students' motivation and learning outcomes (Sholihah, et al., 2016); learning devices through direct teaching models with problem-solving methods developed are declared effective as seen from the achievement and completeness of student learning outcomes which are set in the medium category (Noor et al., 2017); and the use of direct teaching models with problem-solving methods can improve analysis and synthesis skills (Fahrina, et al., 2018; Haryandi, et al., 2013; Refiana, et al., 2016; Rizhan, et al., 2013).

One of the main problems in the current laboratory engineering learning process is the difficulty of students in receiving, responding, and developing the material given by the lecturer. Conventional learning that has been centered on lecturers seems to be detrimental to students, especially students with low abilities. Students seem to tend to be bored in learning and lack the motivation to learn. During the learning process in class, students only pay attention to the lecturer's explanation, then complete the practice questions according to the example. Students are less involved in finding their own material concepts and are not given the opportunity to connect learning materials with everyday life. This is due to the use of learning methods that require a lot of time but the available learning time is not sufficient. In addition, students are also less confident in expressing their opinions in front of their friends. Based on these problems, it can be seen that the basic problem that occurs in carrying out the chemistry learning process is less than optimal classroom management with inefficient methods. Therefore, we need alternative learning that can increase student learning motivation to think critically in participating in learning which can ultimately increase student learning outcomes. One of them is the ARCS model (Fitriani \& Hera, 2020). State the objectives of the work and provide an adequate background, avoiding a detailed literature survey or a summary of the results.

\section{Method}

This research is development research because it is aimed at developing learning tools that integrate ARCS motivation strategies in problem-solving learning models. The learning tools that will be developed are Semester Learning Plans (SLP), Student Worksheet (SW), and Learning Outcomes Tests (LOT). 
This research was conducted in March-May 2021 at the Biology Education Study Program, Faculty of Teacher Training and Education, University of Flores. The subjects of this study were students who programmed laboratory engineering courses in the Biology Education Study Program, totaling 35 people as samples. The development of learning tools refers to the $4 \mathrm{D}$ model, namely the stages of Define, design, development, and Disseminate (Kristanti \& Julia, 2017). However, this research will only be carried out until the third stage that is Develop. The trial of this learning device used a one-group pretest-posttest design. The research data were analyzed using SPSS version 20 including analysis of SLP and SW validation, analysis of learning implementation, analysis of student activity observations, data analysis of student response questionnaires, and analysis of students' critical thinking skills test analysis.

\section{Result and Discussion}

Learning tools developed using the $4 \mathrm{D}$ model consist of Semester Learning Plans (SLP), Student Worksheet (SW), and Learning Outcomes Tests (LOT). The results of the detailed analysis can be described as follows:

\section{Semester Learning Plan (SLP)}

The SLP developed refers to the analysis of students' abilities by considering the depth and breadth of acid-base material. The SLP was further validated by 2 (two) expert teams and obtained instrument reliability analysis data with an average Cronbach's Alpha value of 0.817 . This value indicates that the reliability of the SLP is included in the very high category because it is in the range of the reliable coefficient interval value of $0.71-1.00$. These results indicate that the level of consistency of the SLP is adjusted to the characteristics of the students and the steps of the problem-solving learning model that integrates the ARCS motivation strategy. After conducting the reliability test, the SLP was then tested for validity. A validity test is used to determine the validity of the SLP by using the product-moment correlation (r). Based on the results of the validation obtained $r_{\text {count }} 0.690$. This value compared to $r_{\text {table }} 0.553$ is in the valid category because it is in the assessment range between $0.60-0.799$. The valid category of the measured results explains that the SLP produced is appropriate and valid so that it can be used as a guide for students in carrying out lecture activities for one semester to achieve predetermined learning outcomes (Suheriyanto, et al., 2014).

\section{Student Worksheet (SW)}

SW is a sheet containing teaching materials, which contains structured work steps that must be done by students during the learning process. The SW developed is in accordance with the basic competencies and learning objectives that have been set, and has an attractive appearance (Astari, 2017). The attractive appearance of the SW makes it easier for students to understand the material provided, thus helping students learn actively and independently (Aldresti, et al., 2021). To determine the feasibility of the developed SW, it is necessary to carry out validation by a team of experts who act as validators. A validation test was conducted to see the level of relationship of the developed SW with the material being taught. The results of the SW validation from the 2 validators that have been analyzed, obtained a $r_{\text {count }}$ of 0.748 . The $r_{\text {count }}$ value obtained when compared with the $r_{\text {table }}$ value of 0.433 is in the valid category because it is in the coefficient interval of $0.60-0.799$. The reliability test results obtained from Cronbach's Alpha value of 0.856 are in the very reliable category because they are in the range of $0.71-1.00$. The two results obtained from the validity and reliability tests indicate that the SW developed is consistent and valid by following the material being taught.

\section{Learning Outcomes Test (LOT)}

The development of the learning outcomes test begins by compiling the grid and description test items under the subject matter and course learning achievement (CLA) that have been determined in the semester learning plan (SLP). The LOT instrument was validated by a team of validators. The validation results show that the reliability value of LOT is in the very high category, namely 0.824 because it is in the interval reliable coefficient of $0.71-1.00$. The high value of this reliability proves that the LOT produced is practical and effective in measuring the level of students' understanding of acid-base materials. To see the relationship between each LOT item, a construction and content validity test was conducted (Kereh, et al., 2015). These results indicate the value of the relationship between each item by following the characteristics of the student's ability. This is indicated by the validity value obtained, namely $\mathrm{r}_{\text {count }}$ of 0.701 , where this value is in the range of values of $0.60-0.799$.

\section{Development of Learning Tools}

a. Results of the Defining Stage

The application of the Indonesian National Qualification Curriculum (INQC) in universities for undergraduate programs (S1) is at level six, so students are required to study independently and be actively involved in the learning process (Saputra, et al., 2020). 
In addition, to using student worksheets (SW) as learning media. In the SW, it is implied that the problems encountered in everyday life are related to acid-base materials (Febriani, 2016).

In addition to the initial and final analysis, student analysis was also carried out, where students were grouped by age, gender, intellectual ability, and family background. These characteristics become the basis for group division to facilitate the discussion process, to train students' critical thinking skills in solving real-world problems (Anggreani, 2015; Natalina, 2015; Cahyono, 2017; Rahmatillah, et al., 2017). Other characteristics that form the basis for group division are learning styles, attitudes, and learning motivation. These four other characteristics affect the curiosity of students from the beginning to the end of the learning process, so it does not cause boredom in students (Permana, 2016).

Based on the results of interviews with biology education study program students who program laboratory engineering courses, information was obtained that group discussions are often carried out in the learning process, but do not train students' scientific attitudes and critical thinking skills. During the discussion, the lecturer asked questions about acid-base material related to daily life, students found it difficult to explain the concept. It can be said that the concepts learned by students are not stored in long-term memory.

For this reason, students must be given assignments to do, which include several indicators, namely: a.) Explaining the concept of acid-base, b.) Completing acid-base calculations, c.) Explaining acidbase indicators, and d.) Applying the concept of acidbase in life every day (Kurniawan \& Dewi, 2017). Based on these indicators, a student worksheet (LKM) was prepared as a guide in conducting experiments to solve problems, in order to understand the concept of acid and base through group discussions. The results of the discussion are then presented by each group, and the other groups respond to hone scientific attitudes and students' critical thinking skills (Utari \& Muttaqiin, 2021). In addition to group assignments, independent assignments are also given at the end of the learning process at each meeting and will be collected at the next meeting, as evidence of measuring students' ability to understand the material that has been studied (Sabriani, 2012). Futhermore, the concept analysis is made in the form of a concept map of acid-base material, as a stimulus and stimulation (Resti, 2015). The concept map describes the acid-base material to be studied (Yuniati, 2013).

From the four indicators that have been compiled in the task analysis above, the learning objectives are formulated, namely: a.) Students can explain the concept of acid-base, b.) Students can complete acid-base calculations, c.) Students can define acid-base indicators, and d.) Students can apply the concept of acid-base in daily life.

\section{b. Design Phase Results}

The preparation of the test begins with compiling a grid of critical thinking skills based on indicators and learning objectives. The tests are compiled, then tested on students at the beginning and end of learning activities, to determine the improvement of critical thinking skills (Nurfillaili, et al., 2016). The selection of media in the acid-base learning process integrates ARCS motivation strategies with problem-solving learning models, with the aim of training students' scientific attitude and critical thinking skills, namely using an LKM that has been validated by a validator (Listiani, 2018).

The media used must be narrated in a semester learning plan (RPS) format designed using a format determined by the University, by following indicators of scientific attitude and critical thinking skills. LKM format according to problem-solving learning syntax integrates ARCS strategy, while THB is structured according to learning indicators (Rajabi, et al., 2015). The initial design can be implemented by planning a meeting in the RPS, which consists of three meetings, with an allocation of $3 \times 170$ minutes for each meeting.

In the next step, a learning strategy is developed with the aim of the learning process running effectively according to the specified time allocation and the learning objectives to be achieved. The results of the development contained in the lesson plan contain the learning outcomes of the courses, objectives, and assessment techniques required in each stage of learning (Rahmah, 2014).

\section{c. Development Stage Results}

The validation sheet is an instrument used to measure the validity, practicality, and effectiveness of the validated device (Khomsiatun \& Retnawati, 2015). This sheet was validated by a team of experts on learning tools consisting of a SLP validation sheet, an SW validation sheet, and a OLT validation sheet. The SLP validation sheet consists of the identity of the study program, course identity, course learning achievements, materials, time allocation, learning methods, learning media, learning steps, and learning assessment (Muhsinin \& Fatmawati, 2020). The SW validation sheet consists of content feasibility, presentation feasibility, and language feasibility, as well as layout feasibility, while the OLT validation sheet is designed according to the components, namely an assessment of the construction of the questions, the language of the questions, the material of the questions, 
and the level of difficulty of the questions (Aviyanti, 2015; Fatimah \& Alfath, 2019).

The readability test was carried out on 35 selected students and peer lecturers to assess whether the learning tools in the form of SLP, SW, and OLT could be read easily and clearly (Andari \& Lusiana, 2014).

\section{Implementation of SLP}

Assessment of the implementation of learning is carried out to find out that the learning carried out in the classroom is by following the planned SLP. Aspects observed include teaching and learning activities (introduction, core, and closing) and classroom atmosphere (Amaliah \& Sunarti, 2019). The implementation of the SLP was tested using a Likert scale with the obtained observations being in the good category with a score of 4 for each aspect assessed. The results can be seen in Table 1 .

Table 1. Results of Observation of SLP Implementation

\begin{tabular}{lll}
\hline Rated aspect & Score & Category \\
\hline Introduction & 4 & Good \\
Core & 4 & Good \\
Closing & 4 & Good \\
Class Situation & 4 & Good \\
\hline
\end{tabular}

(Mufidah, 2019)

\section{Student Response}

Observations of student activities were carried out on 35 students during the three lessons. Data from observing student activities can be seen in table 2 .

Table 2. Student Response to ARCS Motivation Strategy in Problem Solving Learning Model

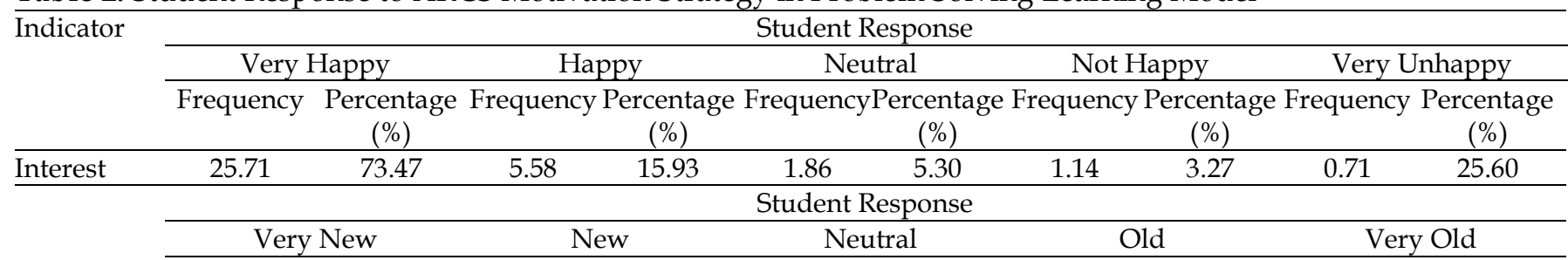

\begin{tabular}{|c|c|c|c|c|c|c|c|c|c|c|}
\hline & Frequency & $\begin{array}{c}\text { Percentage } \\
(\%)\end{array}$ & Frequenc & $\begin{array}{c}\text { Percentage } \\
(\%)\end{array}$ & Frequency & $\begin{array}{c}\text { yercentage } \\
(\%)\end{array}$ & Frequency & $\begin{array}{c}\text { Percentage } \mathrm{F} \\
(\%)\end{array}$ & Frequency & $\begin{array}{c}\text { Percentage } \\
(\%)\end{array}$ \\
\hline Update & 24.57 & 70.19 & 8.43 & 24.07 & 1.86 & 5.31 & 0.14 & 0.41 & 0 & 0 \\
\hline
\end{tabular}

Frequency Percentage Frequency Percentage FrequencyPercentage Frequency Percentage Frequency Percentage $(\%) \quad(\%) \quad(\%)$

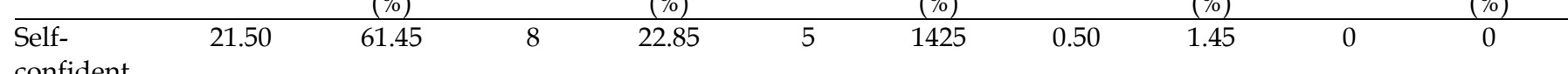

confident

Student Response

\begin{tabular}{|c|c|c|c|c|}
\hline Very Interested & Interested & \multicolumn{2}{|c|}{$\begin{array}{ll}\text { Neutral } & \text { Not Interested }\end{array}$} & \\
\hline
\end{tabular}

Frequency Percentage Frequency Percentage FrequencyPercentage Frequency Percentage Frequency Percentage

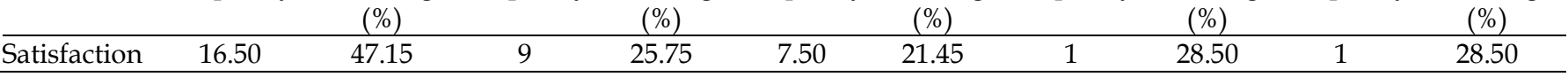

Table 2. data shows that in the interest indicator, the percentage of student responses is $73.47 \%$ very happy, $15.93 \%$ happy, $5.3 \%$ neutral, $3.27 \%$ not happy, and $2.56 \%$ very dissatisfied. On the indicator of recency, the student response is $70.10 \%$ very new, $24.07 \%$ new, $5.31 \%$ neutral, and $0.41 \%$ old. For the indicator of self-confidence, the student response is $61.45 \%$ strongly agree, $22.85 \%$ agree, $14.25 \%$ neutral, and $1.45 \%$ disagree, while the student response satisfaction indicator is $47.15 \%$ very interested, $25.75 \%$ interested, $21.45 \%$ neutral, $2.85 \%$ disinterested and very disinterested. From the results of the student response questionnaire on learning devices using the ARCS motivation strategy in the problem-solving learning model, it gave a positive response, because students were motivated to learn acid-base material and student learning outcomes increased.

\section{Learning Outcomes}

The interpretation of the effectiveness of the NGain value (\%) is categorized in Table 3.

Table 3. Category Interpretation of N-Gain Effectiveness

\begin{tabular}{ll}
\hline Percentage $(\%)$ & Category \\
\hline$<40$ & Ineffective \\
$40-45$ & Less Effective \\
$56-75$ & Effective Enough \\
$>76$ & Effective \\
\hline
\end{tabular}
(Juniati, et al., 2020)

Learning outcomes data were analyzed using the $\mathrm{N}$-Gain Score test to see the effectiveness of learning 
outcomes using the ARCS motivation strategy in problem-solving learning models, which can be seen in Table 4 and 5.

In Table 4, the results of the N-Gain Score test calculation in the productive class are $78.58 \%$. The results are included in the effective category, with a minimum N-Gain Score value of $60 \%$ and a maximum of $100 \%$. The average N-Gain Score in the trial class (Table 5) is $70.14 \%$ and is included in the quite effective category, with a minimum N-Gain Score value of $57.14 \%$ and a maximum of $90 \%$. These data indicate that learning using the ARCS motivation strategy in the problem-solving learning model in the trial class is quite effective and in the productive class it is effective in improving student learning outcomes (Solikha, et al., 2020).

Table 4. N-Gain Score Test Calculation Results of Productive Class

\begin{tabular}{|c|c|}
\hline \multirow[t]{2}{*}{ Number } & Productive Class \\
\hline & N-Gain Score (\%) \\
\hline 1 & 76.92 \\
\hline 2 & 84.62 \\
\hline 3 & 100.00 \\
\hline 4 & 78.57 \\
\hline 5 & 78.57 \\
\hline 6 & 75.00 \\
\hline 7 & 71.43 \\
\hline 8 & 90.91 \\
\hline 9 & 61.54 \\
\hline 10 & 76.92 \\
\hline 11 & 78.57 \\
\hline 12 & 69.23 \\
\hline 13 & 100.00 \\
\hline 14 & 78.57 \\
\hline 15 & 71.43 \\
\hline 16 & 73.33 \\
\hline 17 & 71.43 \\
\hline 18 & 83.33 \\
\hline 19 & 64.29 \\
\hline 20 & 76.47 \\
\hline 21 & 86.67 \\
\hline 22 & 85.71 \\
\hline 23 & 60.00 \\
\hline 24 & 100.00 \\
\hline 25 & 80.00 \\
\hline 26 & 66.67 \\
\hline 27 & 80.00 \\
\hline 28 & 83,33 \\
\hline 29 & 75.00 \\
\hline 30 & 68.75 \\
\hline 31 & 75.00 \\
\hline 32 & 91.67 \\
\hline 33 & 75.00 \\
\hline 34 & 81.25 \\
\hline 35 & 80.00 \\
\hline Average & 78.58 \\
\hline Minimum & 60.00 \\
\hline Maximum & 100.00 \\
\hline
\end{tabular}

Table 5. N-Gain Score Test Calculation Results of Trial Class

\begin{tabular}{ll}
\hline Number & Trial Class \\
\cline { 2 - 2 } & N-Gain Score (\%) \\
\hline 1 & 75.00 \\
2 & 66.67 \\
3 & 78.57 \\
4 & 66.67 \\
5 & 73.68 \\
6 & 66.67 \\
7 & 66.67 \\
8 & 57.14 \\
9 & 57.14 \\
10 & 87.50 \\
11 & 6.00 \\
12 & 81.82 \\
13 & 64.29 \\
14 & 62.50 \\
15 & 66.67 \\
16 & 68.75 \\
17 & 71.43 \\
18 & 75.00 \\
19 & 9.00 \\
20 & 66.67 \\
Average & 70.14 \\
Minimum & 57.14 \\
Maximum & 90.00 \\
\hline
\end{tabular}

\section{Conclusion}

Based on the results and discussion, it can be concluded that the development of learning tools by applying the ARCS motivation strategy in problemsolving learning models is effective in improving student learning outcomes of the Biology Education Study Program, the University of Flores on acid-base material, laboratory engineering courses.

\section{References}

Aldresti, F. \& Erviyenni, Haryati, S. (2021). Development of Collaborative Learning-based Electronic Student Worksheet (E-SW) for Mathematics and Natural Sciences Education Basics. PENDIPA Journal of Science Education, 5(3), 292-299. https://doi.org/10.33369/pendipa.5.3.292-299

Amaliah, Q. \& Sunarti, T. (2019). Implementation of Case Based Learning (CBL) Model to Improve Argumentation Skills of Class X Students of Madrasah Aliyah Bilingual Krian. Inovasi Pendidikan Fisika, 8(2), 613-617. https://doi.org/10.26740/ipf.v8n2.p\%25p

Andari, T. \& Lusiana, R. (2014). Development of Learning Devices Using Quantum Learning Approach Based on Needs Assessment on Euclides' n-Space Material. JIPM: Jurnal Ilmiah 
Pendidikan Matematika, 3(1),

http://doi.org/10.25273/jipm.v3i1.488

7-17.

Anggreani, C. (2015). Improving Critical Thinking Skills through Environmental-based Experimental Methods. Jurnal Pendidikan Usia Dini, $\quad 9(2)$, 343-361. https:// doi.org/10.21009/JPUD.092.09

Astari, T. (2017). Development of Student Worksheets (SW) Based on Realistic Approaches to Improve Learning Outcomes of Grade IV Elementary School Students. Jurnal Pelangi, 9(2), 150-160. https://doi.org/10.22202/jp.2017.v9i2.2050

Aviyanti, Z. (2015). Validity of 5M Oriented SW Materials for Environmental Change and Waste Recycling to Train Students to Solve Problems. Bioedu: Berkala Ilmiah Pendidikan Biologi, 4(1), 816821. Retrieved from: https://ejournal.unesa.ac.id/index.php/bioedu Larticle/view/10941/10471

Cahyono, B. (2017). Analysis of Critical Thinking Skills in Solving Problems in terms of Gender Differences. Aksioma, 8(1), 50-64. https://doi.org/10.26877/aks.v8i1.1510

Fahrina, Arifuddin, M., \& Salam, A. (2018). Improving the Synthesis Analysis Ability of Class X MIA 6 SMAN 2 Banjarmasin through Direct Teaching Model with Problem Solving Method. Berkala Ilmiah Pendidikan Fisika, 6(1), 98-117. http://dx.doi.org/10.20527/bipf.v6i1.3897

Fatimah, L. U. \& Alfath, K. (2019). Analysis of Problem Difficulty, Distinguishing Power, and Distractor Function. Jurnal Komunikasi dan Pendidikan Islam, 8(2), 37-64. https://doi.org/10.36668/jal.v8i2.115

Febriani, M. (2016). Utilization of Student Worksheets to Increase Student Activity: A Study on the Application of Lesson Study in Indonesian Language Textbook Courses. Jurnal Pendidikan Bahasa dan Sastra, 16(2), 203-212. https://doi.org/10.17509/bs_jpbsp.v16i2

Fitriani, N. \& Hera, R. (2020). The Effect of ARCS Learning Model (Attention, Relevance, Confidence, Satisfaction) on Increasing Student Activities and Learning Outcomes on Human Respiratory System Material at SMP Negeri 5 Seunagan, Nagan Raya Regency. Bionatural, 7(2), 36-44. Retrieved from: https://ejournal.stkipbbm.ac.id/index.php/bio/ article/view/524/465

Haryandi, S., Zainuddin, \& Suyidno. (2013). Improving Students' Synthesis Analysis Ability through the Application of Direct Teaching with Problem Solving Methods. Berkala Ilmiah Pendidikan Fisika, 1(3), 265-270. http://dx.doi.org/10.20527/bipf.v1i3.885
Juniati, N., Jufri, A. W., \& Yamin, M. (2020). The Use of Learning Multimedia to Improve Students' Scientific Literacy. Jurnal Pijar MIPA, 15 (4), 315 319. http://dx.doi.org/10.29303/jpm.v15i4.1975

Kereh, C. T., Liliasari, Tjiang, P. C., \& Sabandar, J. (2015). Validity and Reliability of Basic Mathematics Test Instruments Related to the Introduction to Core Physics. Jurnal Inovasi dan Pembelajaran Fisika, 2(1), 36-46. https://doi.org/10.36706/jipf.v2i1.2352

Khairani, I. \& Safitri, R. (2017). Application of Problem Solving Learning Methods to Improve Student Learning Outcomes on Business and Energy Materials at MAN Rukoh Banda Aceh. Jurnal Pendidikan Sains Indonesia, 5(2), 32-40. https://doi.org/10.24815/jpsi.v5i2.9814

Khomsiatun, S. \& Retnawati, H. (2015). Development of Learning Tools with Guided Discovery to Improve Problem Solving Ability. Jurnal Riset Pendidikan Matematika, 2(1), 92-106. https://doi.org/10.21831/jrpm.v2i1.7153

Kristanti, D. \& Julia, S. (2017). Development of 4-D Model Mathematics Learning Tools for Inclusive Classes as an Effort to Increase Students' Interest in Learning. Jurnal MAJU, 4(1), 38-50. Retrieved from:

https://ejournal.stkipbbm.ac.id/index.php/mtk /article/view/71/61

Kurniawan, D. \& Dewi, S. V. (2017). Development of Learning Devices with Screencast-O-Matic Media for Calculus 2 Course using the 4D Thiagarajan Model. Jurnal Siliwangi, 3(1), 214-219. https://doi.org/10.37058/ispendidikan.v3i1.193

Listiani, I. (2018). Effectiveness of Worksheets for Empowering Critical Thinking Skills for Elementary School Teacher Education Students. Jurnal Penelitian Pendidikan, 35(1), 17-25. 10.15294/ipp.v35i1.13547

Mufidah, E. (2019). Science Practicum-Based Learning to Train Scientific Communication Skills for PGMI Students. KARANGAN: Jurnal Kependidikan, Pembelajaran, dan Pengembangan, 1(2), 121-140. Retrieved from https://ejournal.billfath.ac.id/index.php/karan gan/article/view/16/15

Muhsinin, U. \& Fatmawati, K. (2020). Validity and Practicality of Semester Learning Plan (SLP) Integrated Research-Based Learning. Jurnal Ilmiah Universitas Batanghari Jambi, 20(1), 201-206. http://dx.doi.org/10.33087/jiubj.v20i1.791

Natalina, D. (2015). Cultivating Critical Thinking Behavior Since Early Childhood. Cakrawala Dini, $5(1)$,

1-6. https://doi.org/10.17509/cd.v6i1.10508 
Noor, M., Zainuddin, \& Miriam, S. (2017). Development of Physics Science Learning Devices through Direct Teaching Model with Problem Solving Method. Berkala Ilmiah Pendidikan Fisika, 5(3), 328-339. http://dx.doi.org/10.20527/bipf.v5i3.3958

Nurfillaili, U., Yusuf, M. T., \& Anggereni, S. (2016). Development of Eye Cognitive Learning Outcomes Test Instruments Physics Lessons on Business and Energy subjects at Jeneponto State Senior High School Class XI Semester I. Jurnal Pendidikan Fisika, 4(2), 83-87. https://doi.org/10.24252/jpf.v4i2.3709

Permana, A. (2016). The Influence of Learning Style and Student's Learning Motivation on Learning Ability of Basic Natural Sciences. Jurnal Formatif, 6(3), 276-283. http://dx.doi.org/10.30998/formatif.v6i3.999

Purwanti, S. \& Manurung, S. (2015). Analysis of the Effect of Problem Solving Learning Models and Scientific Attitudes on Physics Learning Outcomes. Jurnal Pendidikan Fisika, 4 (1), 57-62. https://doi.org/10.22611/jpf.v4i1.2569

Priska, M. Pendy, A., Peni, N., \& Carvallo, L. (2020). Development of Problem Based Learning in Chemistry Courses to Improve Students' Critical Thinking Ability. Jurnal Pedagogia, 9 (2), 163 177.

https:// doi.org/10.21070/pedagogia.v9i2.789

Rahmah, N. (2014). Development of Learning Strategies in Mathematics Education. AlKhwarizmi, 2(2), $115 \quad-\quad 126$. https://doi.org/10.24256/ipmipa.v2i2.118

Rahmatillah, S., Hobri, \& Oktavianingtyas, E. (2017). Critical Thinking Ability Level of Students in Solving Arithmetic Sequences and Series Problems at SMAN 5 Jember. Kadikma, 8(2), 5160. https://doi.org/10.19184/kdma.v8i2.6400

Rajabi, M., Ekohariadi, \& Buditjahjanto, I. G. P. A. (2015). Development of Learning Devices for Operating System Installation with Project-Based Learning Model. Jurnal Pendidikan Vokasi: Teori dan Praktek, 3(1), 48-54. Retrieved from: https://ejournal.unesa.ac.id/index.php/pendidi kan-vokasi-teori-danprak/article/view/13561/4808

Refiana, R., Jamal, M. A., \& Hartini, S. (2016). Improving the Analytical Ability of Class X MS3 SMAN 2 Banjarmasin Students on Circular Motion Materials through Direct Teaching with Problem Solving Methods. Berkala Ilmiah Pendidikan Fisika, 4(1), 64-72. http://dx.doi.org/10.20527/bipf.v4i1.1048

Resti, V. D. A. (2015). Analysis of Student Creativity in Compiling a Concept Map in the form of an E-
Mind Map Based on Neuroscience Studies. Jurnal Pendidikan Biologi, 6(2), 128-134. http://dx.doi.org/10.17977/um052v6i2p128-134

Rizhan, M., Jamal, M. A., \& Hartini, S. (2013). Improving Students' Synthesis Analysis Ability with Problem Solving Method through Direct Teaching. Berkala Ilmiah Pendidikan Fisika, 1(3), 216-223.

http://dx.doi.org/10.20527/ bipf.v1i3.880

Sabriani, S. (2012). Implementation of Giving Structured Tasks with Feedback on Direct Learning to Improve Student Motivation and Learning Outcomes. Jurnal Chemica, 13(2), 39-46. https://doi.org/10.35580/chemica.v13i2.625

Saputra, A. R., Amin, M., \& Lestari, U. (2020). Exploration Study of Mammal Embryo Development Lecture on Animal Development Structure II. Jurnal Pendidikan: Teori, Penelitian, dan Pengembangan, 5(9), 1323-1326. Retrieved from:

http://journal.um.ac.id/index.php/jptpp/articl e/view/14050

Sholihah, M., Yuliati, L., \& Wartono. (2016). The Role of TPACK on the Ability to Develop Learning Tools for Prospective Physics Teachers in Post-Pack Learning. Jurnal Pendidikan: Teori, Penelitian, dan Pengembangan, 1(2),144-153. https://dx.doi.org/10.17977/ip.v1i2.6115

Solikha, N., Suchainah, \& Rasyida, I. (2020). The Effectiveness of Schoology-Based E-Learning Learning on Increasing Student Activity and Learning Outcomes X IPS MAN Pasuruan City. Jurnal Ilmiah Edukasi dan Sosial, 11(1), 31-42. Retrieved from: https://jiesjournal.com/index.php/jies/article/ view $/ 221 / 153$

Suheriyanto, Basuki, I., \& Soenarjo. (2014). Development of Learning Devices Based on Virtual Computers and Video Media in Direct Learning Models (Studies on Network Operating System Installation Training Courses at SMKN 2 Tarakan). Jurnal Pendidikan Vokasi: Teori dan Praktek, 2(1), 1-11. Retrieved from https://ejournal.unesa.ac.id/index.php/pendidi kan-vokasi-teori-danprak/article/view/8695/3958

Sukaesih, S. (2011). Analysis of Scientific Attitudes and Student Responses to the Application of Practicum-Based Learning Models. Jurnal Penelitian Pendidikan, 28(1), 77-85. https://doi.org/10.15294/jpp.v28i1.5628

Utari, M. A. \& Muttaqiin, A. (2021). The Application of Make A Match Type Cooperative Learning with Critical Reading Activities to Improve Students' Critical Thinking on the Interaction of Living 
Things with the Environment. INKUIRI: Jurnal

Pendidikan IPA, 10(1), 56-66.

https://doi.org/10.20961/inkuiri.v10i1.44189

Wahidah, Salam, A., \& Suyidno. (2019). Direct Teaching, ARCS Motivation Strategy, Problem Solving Methods, and Learning Outcomes. Jurnal Vidya Karya, 34(2), 110-121. http://dx.doi.org/10.20527/jvk.v34i2.7569

Yardi. (2015). Efforts to Increase Students' Learning Motivation with an Inquiry Approach in Physics Lessons for Class XI Multimedia Semester 1 of SMK Negeri 1 Gunung Talang, Solok Regency, 2012/2013 Academic Year. Jurnal Educatio, 1(1), 53-67. Retrieved from:

https://jurnal.iicet.org/index.php/jedu/article/view/6/16

Yuniati, S. (2013). Concept Map (Mind Mapping) in Algebraic Structure Learning. Gamatika, 3(2), 129139. from: http://journal.unipdu.ac.id:8080/index.php/ga matika/article/view/372/335 